ISSN $1978-3000$

\title{
Respon Pemberian “Blok Suplemen” Berbasis Bahan Lokal Terhadap Pertambahan Bobot Sapi Bali
}

\author{
Response of Supplementation of Blocks Made of Local Ingredients \\ On Body Weight of Bali Cattle
}

Sri Arnita Abutani, Syafrida Rahim, Noverma

Fakultas Peternakan Univ. Jambi, 0741- 582907

\begin{abstract}
The aim of this research was to evaluate the response of supplementation of blocks made of local ingredients on body weight of Bali cattle. There were 3 cattle allocated into three treatments, R0 (ad lib. Forage) as control, R1 (ad lib. Forage + LAM block), and R2 (ad lib. Forage + SAM block) in Latin Square experimental design. LAM block contains palm sugar, rice bran, corn, palm oil sludge, lime, urea, salt, TSP, Cement, premix, yeast ) and SAM block consists of palm sugar, rice bran, corn, palm fiber, lime urea, salt, TSP, cement, premix, yeast .Variables collected were ration dry matter intake (DMI), body weight gain, and ration efficiency. Results showed that both blocks increased body weight $(0.2-0.45 \mathrm{~kg})$ and the efficiency of ration $(1.2-2.9)$, but the DMI didn't change relatively.
\end{abstract}

Keywords : Supplement Block, Palm Oil Sludge and Palm Fiber

\begin{abstract}
ABSTRAK
Penelitian ini bertujuan untuk melihat respon pemberian blok suplemen berbasis bahan local terhadap pertambahan bobot badan sapi Bali. Untuk itu dilakukan penelitian dengan menggunakan 3 ekor sapi Bali jantan umur 1-1.5 tahun. Rancangan yang digunakan adalah Rancangan Bujur Sangkar Latin dengan 3 perlakuan dan 3 priode. Perlakuan yang diberikan hádala Ro (hijauan ad limitum ) yang akan dijadikan sebagai control, R1 ( hijauan ad libitum + Lam Blok), dan R2 ( hijauan ad limitum + SAM Blok ). Peubah yang diamati konsumsi bahan kering ransum, pertambahan bobot badan dan efisiensi penggunaan ransum. Hasil menunjukkan bahwa pemberian blok suplemen berupa LAM Blok dan SAM Blok dapat meningkatkan bobot badan, dan efisiensi penggunaan ransum tetapi tidak meningkatkan konsumsi ransum.
\end{abstract}

Kata Kunci.; Blok Suplemen , Lumpur sawit dan Serat Sawit

\section{PENDAHULUAN}

Pemeliharaan ternak sapi di masyarakat perdesaan masih bersifat tradisional. Pemberian pakan hanya berupa rumput lapangan tanpa adanya sentuhan teknologi. Kondisi ini disebabkan karena ketidak tahuan peternak terhadap inovasi baru dalam pemeliharaan ternak sapinya. Mereka lebih cendrung menerapkan sistim pemeliharaan yang turun temurun. Oleh karena itu umumnya produktivitas sapi yang dipelihara tidak mencapai pertumbuhan yang optimum.

Seiring dengan permasalahan di atas sebenarnya banyak limbah yang dapat digunakan untuk ternak sapi antara lain, limbah perkebunan sawit. Sebagai provinsi penghasil sawit limbah ini tentu saja diproduksi secara besar-besaran, dan ini bisa dijadikan pakan ternak sapi dengan dijadikan pakan suplemen berupa blok yang dicampur dengan bahan pakan 
spesifik lokasi. Irsan (1997) menyatakan bahwa pakan suplemen berbentuk blok memberikan dampak positif terhadap pertumbuhan ternak sapi.

Pertumbuhan adalah pertambahan bobot badan atau ukuran tubuh sesuai dengan umur sedangkan perubahan ukuran tubuh serta fungís dari berbagai bagian tubuh semenjak embrio sampai mencapai dewasa tubuh. Proses pertumbuhan dimulai semenjak awal terjadinya pembuahan yang menghasilkan embrio hingga pedet lahir dan dilanjutkan sampai sapi menjadi dewasa pertumbuhan ini meliput pertumbuhan sel, organ dan jaringan dari individu ( Sugeng, 2002). Faktor yang mempengaruhi pertumbuhan adalah makanan, umur, bangsa, jenis kelamin, bobot lahir, dan lingkungan. Siregar (2003) menyatakan bahwa pertumbuhan bobot badan sapi ditentukan oleh faktor jenis sapi, jenis kelamin, umur, ransum, atau pakan yang diberikan dan teknik pengelolaannya. Pertumbuhan secara umum diketahui dengan pengukuran kenaikan berat badan yang dengan mudah dapat dilakukan lewat penimbangan berulang dalam waktu tertentu serta dapat dicatat pertambahan bobot badan perhari, minggu dan bulan (Murtidjo, 2000)

Pakan adalah sesuatu yang dapat dimakan dan dicerna baik sebagian maupun secara keseluruhan dengan idak mengganggu kesehatan ternak yang memakannya. Pemberian pakan pada ternak sapi diberikan acuan $10 \%$ dari bobot badan dalam sehari serta kosentrat dapat diberikan sebanyak 2.5-3 \% dari bobot badan sapi (Bandini, 1999). Pemberian pakan berbentuk blok sebagai suplemen dapat meningkatkan bobot badan. Oleh Hatmono dan Hastoro, 1997 dinyatakan konsumsi UMB (urea molasses Blok ) pada sapi potong dapat mencapai 350 g/ ekor/ hari dan sekitar 120 g/ekor/hari untuk ternak kecil seperti kambing dan domba .

Limbah industri pengolahan kelapa sawit d Indonesia cukup melimpah tetapi penggunaannya lumpur sawit masih terbatas. Pengolahan kelapa sawit menjadi minyak sawit akan menghasilkan limbah dinataranya berupa bungkil inti sawit, serat sawit dan lumpur sawit. Lumpur sawit merupakan larutan buangan yang dihasilkan selama proses ekstrasi minyak. Untuk setiap ton hasil akhir hasil minyak sawit akan dihasilkan antara 2-3 ton lumpur sawit.. sebagai komponen terbesar dalam bahan ini adalah air (95\%), padatan (4-5\%) dan sisa minyak sebesar $0.5-1 \%$. Limbah ini biasanya dibuang dan langsung dialirkan ke sungai sekitar pabrik sehingga menyebabkan gangguan ekologi. Melihat adanya padatan dan beberapa zat makanan yang terkandung di dalamnya, limbah ini sebenarnya masih dapat diandalkan potensinya baik sebagai pupuk maupun campuran pakan ternak (BPS, 2005), sedangkan serat sawit pemnfaatannya sebagai pakan ternak sapi dapat berfungsi sebagai substitusi rumput gajah sebanyak $50 \%$, namun bila lebih dari batas itu akan mengakibatkan selera makan sapi, kecernaan energi, retensi nitrogen pakan dan pertumbuhan akan terganggu.

Pakan suplemen dapat berfungsi sebagai pakan pemicu pertambahan bobot badan sapi, juga meningkatkan populasi mikroba didalam rumen $\mathrm{Hal}$ tersebut akan merangsang ternak sapi untuk menambah jumlah konsumsi pakan sehingga akan meningkatkan produksi ( Karta disastra, 1997). Manfaat pemberian pakan suplemen dari aspek fisiologis ternak terhindar dari defisiensi vitamin dan defisiensi mineral,ternak terhindar dari malnutrisi . respon suplemen yang menyediakan nutrien untuk mikroorganisme rumen ditandai oleh 
Tabel 1. Susunan Formula Blok Suplemen ( LAM Blok dan SAM Blok) (\%)

\begin{tabular}{|l|l|c|l|c|}
\hline No. & Bahan Baku & $\begin{array}{c}\text { Formula I } \\
\text { (LAM BLOK) }\end{array}$ & Bahan Baku & $\begin{array}{c}\text { Formula II } \\
\text { (SAM BLOK) }\end{array}$ \\
\hline 1. & Gula aren & 25 & Gula aren & 17 \\
\hline 2. & Dedak Padi & 23 & Dedal Padi & 27 \\
\hline 3. & Jagung & 6 & Jagung & 10 \\
\hline 4. & Lumpur Sawit & $\mathbf{2 8}$ & Serat sawit & 28 \\
\hline 5. & Kapur & 8 & Kapur & 8 \\
\hline 6. & Urea & 6 & Urea & 6 \\
\hline 7. & garam & 1 & garam & 1 \\
\hline 8. & TSP & 1 & TSP & 1 \\
\hline 9. & Semen & 1 & Semen & 1 \\
\hline 10. & Premix & 0.5 & Premix & 1 \\
\hline 11. & Ragi & 0.5 & Ragi & 1 \\
\hline & Jumlah & 100 & Jumlah & 100 \\
\hline
\end{tabular}

peningkatan laja pencernaan serat dan peningkatan proporsi protein mikrobial pada saat akhir pencernaan.

\section{MATERI DAN METODE}

Penelitian ini menggunakan 3 ekor sapi Bali Jantan berumur 1-1.5 tahun, yang dirancang dengan Rancangan Bujur sangrar Latin, dengan 3 perlakuan dan 3 priode. Perlakuan yang diberikan adalah Ro (hikauan ad lib ) , R1 ( hijauan ad lib + LAM Blok) dan R2 ( hijauan ad lib +SAM Blok). Peubah yang diamati pertambahan bobot badan, konsumsi ransum dan efisiensi penggunaan ransum. Seluruh data yang diperoleh akan diolah dengan analisis sidik ragam sesuai dengan rancangan yang digunakan. Bahan penyusun Blok Suplemen adalah : aren, dedakl padi , jagung, kapur, urea, TSP, garam, ragi, premix semen, lumpur sawit dan serat sawit. Susunan blok sawit yang digunakan disajikan pada Tabel 1.

\section{HASIL DAN PEMBAHASAN}

Hasil analisa kedua blok suplemen

Tabel 2. Hasil Analisis Blok Suplemen LAM Blok dan SAM Blok

\begin{tabular}{|c|c|c|c|c|c|c|c|c|c|}
\hline \multirow[b]{2}{*}{ No. } & \multirow{2}{*}{$\begin{array}{c}\text { Bahan } \\
\text { Makanan }\end{array}$} & \multicolumn{8}{|c|}{ Zat Makanan (\%) } \\
\hline & & BK & TDN & PK & $\mathrm{Abu}$ & SK & LK & $\begin{array}{c}\text { Beta - } \\
\mathrm{N}\end{array}$ & $\mathrm{Ca}$ \\
\hline \multirow[t]{2}{*}{1 . } & LAM & 79.81 & 77.15 & 18.53 & 10.99 & 6.37 & 6.66 & 37.26 & 2.97 \\
\hline & BLOK & 69.15 & 62.35 & 12.17 & 10.77 & 11.54 & 3.18 & 31.49 & 0.72 \\
\hline
\end{tabular}

Ket. Analisa Proximat Laboratorium Ilmu dan teknologi pakan Fakultas Peternakan IPB, (2003) 
LAM blok Dan SAM Blok disajikan pada Tabel 2. Pada tabel tersebut dapat dikemukakan bahwa kandungan PK dan TDN antara kedua Bahan limbah sawit, lumpur sawit blok ternyata lebih tinggi dari serat sawit blok.

\section{Konsumsi Bahan Kering Ransum}

Konsumsi bahan kering ransum, pertambahan bobot badan dan efisiensi ransum dari masig-masing perlakuan disajikam pada Tabel 3.

Konsumsi bahan kering ransum tidak berbeda antar perlakuan, walaupun ada kecendrungan untuk sapi yang diberi lumpur sawit blok (LAM Blok) meningkat. Kondisi ini dimungkinkan karena pemberian lam blok dan sam blok pada sapi tersedia setiap saat, sehingga ternak cendrung lebih sering mengkonsumsi blok suplemen.

Pada pertambahan bobot badan sapi sebagai pemberian Lam Blok dan Sam blok, terlihat juga bahwa perlakuan yang diberikan pada sapi yakni rumput ad lib dan Lamb blok (R2) dan SAM Blok cendrung meningkat dibandingkan dengan sapi yang diberi hanya rumput (Ro). Walaupun tidak berbeda pertambahan bobot badan dari sapi yang memperoleh Lam Blok (R1) dari data yang ada terlihat adanya peningkatan PBB dibandingkan dengan sapi yang memperoleh Sam Blok (R3). Peningkatan pertambahan bobot badan pada sapi yang memperoleh Lamb Blok (R1) di duga karena kandungan protein pada suplemen LAM Blok lebih tinggi dibandingkan dengan suplemen Sam Blok yakni $18.53 \%$ dan TDN $77.15 \%$. Tomaszewska et al. (1993) menyatakan bahwa ada korelasi antara komposisi protein kasar dengan pertambahan bobot badan. Ternak yang mendapat proetein lebih tinggi mempunyai pertambahan bobot badan yang lebih tinggi (Parakkasi. 1999). Pakan suplemen berbentuk blok dapat memperbaiki kondisi lingkungan rumen karena suplemen blok dapat menyediakan zat essensial untuk pertumbuhan mikroba - Pakan suplemen dapat meningkatkan populasi mikroba di dalam rumen. Selanjutnya diduga ragi yang digunakan dalam lam blok dapat juga merangsang peningkatan pertambahan bobot badan. Seperti yang dikemukakan Pathak et al ( 2000). Bahwa ragi merupakan sumber vitamin, enzim dan kofaktor untuk meningkatkan aktifitas mikroba dalam rumen.

\section{Efisiensi Penggunaan Ransum}

Efisiensi Pengunaan Ransum terbesar diperoleh dari sapi yang mendapatkan rumput ad lib + Lam Blok (R1). Berati lumpur sawit Blok (Lam Blok) yang diberikan pada sapi lebih dapat memperbaiki kualitas dari pakan yang

Tabel 3. Rataan Konsumsi Bahan kering Ransum, Pertambahan Bobot Badan dan Efisiensi Ransum

\begin{tabular}{lccc}
\hline \multirow{2}{*}{ Peubah } & \multicolumn{3}{c}{ Perlakuan } \\
\cline { 2 - 4 } & Ro & R1 (LAM) & R (SAM) \\
\hline Konsumsi BK ransum (gr/ekor/hr) & $2121.31^{\mathrm{a}}$ & $2493.25^{\mathrm{a}}$ & $2362.33^{\mathrm{a}}$ \\
\hline Pertambahan Bobot Badan (gr/ekor/hr) & $166.67^{\mathrm{a}}$ & $541.67^{\mathrm{b}}$ & $450.00^{\mathrm{b}}$ \\
\hline Efisiensi Penggunaan Ransum & $1.16^{\mathrm{a}}$ & $2.97^{\mathrm{b}}$ & $2.59^{\mathrm{b}}$ \\
\hline Superskrip berbeda pada kolom yag sama menunjukkan pengaruh sangat nyata $(\mathrm{p}<0.01)$
\end{tabular}


diberikan . Ali dan Noeriyanto (2000) dalam Setiadi dkk ( 2002) bahwa perbaikan kualitas pakan akan meningkatkan efisiensi. Semakin meningkat angka efisiensi maka semakin efisien ternak tersebut memanfaatkan pakan menjadi daging. Selanjutnya dikemukakan bahwa ternak yang mendapatkan protein lebih tinggi akan lebih efisien dalam menggunakan makanan.

\section{SIMPULAN}

Pemberian pakan suplemen Blok multinutrien dari limbah sawit (lumpur sawit/Lam Blok dan serat sawit/ Sam Blok) berbasis bahan pakan local dapat meningkatkan pertambahan bobot badan 0.3 - 0.4 gram/ekor/hari. Meningkatkan efisiensi ransum (1.2-2.9)

\section{DAFTAR PUSTAKA}

Badan Pusat Statistik. 2005. Kelapa Sawit - Usaha Budidaya, pemanfaatan Hasil, dan aspek Pemasaran. Penebar Swadaya, Jakarta.

Bandini. Y. 1999. Sapi Bali. Penebar Swadaya. Jakarta.

Hatmono, H., I. Hastoro. 1997. Urea Molasses Blok. Pakan Suplemen
Ternak Ruminansia. PT Trubus Agriwidya, Jakarta.

Irsan, R. U. Zaituni, R. Jurnida, R. Yose. 1997. Peningkatan Productivitas SApi dengan Menggunakan Saka Blok di Sumatera Barat. Facultas Peternakan Unov Andalas.

Kartadisastra, H.R., 1997. Tata Laksana dan Pengolahan Pakan Ternak Ruminansia. Kanisius. Yogyakarta.

Murtidjo, A. B. 2000. Beternak Sapi Potong. Penerbit Kanisius. Yogyakarta.

Parakkasi, A. 1999. ilmu Nutrisi dan Makanan Ternak Ruminansia. Universitas Indonesia Press.

Pathak., N.N., L. C. Chowdhury dan D.N. Kamra. 2000. Effect Of Dietary Supplementation UIT Yeast Cell (saccharomyces, cerevisiae) On Nutrient Utilizaion and Growth Response in Cross Breed. Ajas. Vol. 11 : 268-271.

Setiadi B., M.H. Togotrop dan Muryanto. 2002. Introduksi usa Ternak Sapi Dalam Sistem Usaha Tani, di daerah Pasang Surut. Pusat penelitian dan Pengembangan peternakan Bogor.

Siregar, S. B. 2003. Penggemukkan Sapi . Penebar Swadaya, Jakarta.

Sugeng, Y.B. 2002. Sapi Potong. Penebar Swadaya, Jakarta 